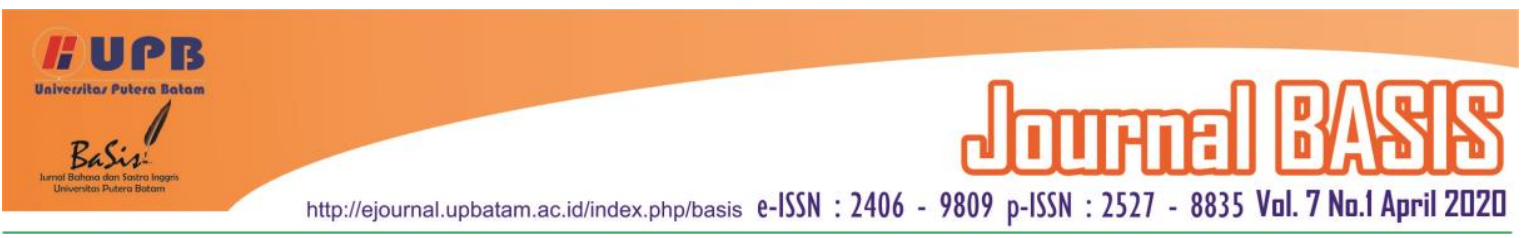

\title{
ENGLISH TEACHER PERSPECTIVE ON LEARNING ENGLISH AT SMA KARTIKA VIII-1 SOUTH JAKARTA
}

\author{
Sjafty Nursitti NP Maili ${ }^{1}$ \\ University of Indraprasta PGRI Jakarta \\ sjaftym@gmail.com ${ }^{l}$ \\ Endang Sondari ${ }^{2}$ \\ University of Indraprasta PGRI Jakarta \\ endang-sondari@yahoo.com ${ }^{2}$
}

\begin{abstract}
The objective of this study is to describe the perspective of English teachers about the 2013 curriculum, the implementation of English learning, the expectations of English teachers about the learning English. This research has been conducted at SMA Kartika VIII-1 Srengseng Sawah Jakarta Selatan It was a qualitative research that the researcher described the phenomenon happened and analysis it. The data was obtained by observation and interview. There are some steps as follow; First, Observation. It was done when the English teacher teach to the students; Second, Interview. It was taken when the English teacher taking a rest. The result of this research as follow: 1. The English teachers perspective about the concept of 2013 curriculum are positive; 2. The English teachers perspective about the implementation of learning English based on the 2013 curriculum was not maximal because there is no correspondence between the hours only 2 hours and the material taught by the English teacher; 3. English teachers expectation of learning English that is a change from 2 hours a week to 4 hours in a week.
\end{abstract}

Key words: Curriculum 2013; English teacher; perspective

\section{INTRODUCTION}

Hasbullah, M (2015) stated that The education function found in UndangUndang Republik Indonesia Nomor 20 Tahun 2003 tentang Sistem Pendidikan Nasional Pasal 3 as follow: National education function to develop the abilities and form a character then the nation's civilization be dignified in order to educate the life of a nation, the aim to develop the students' ability so that be a spiritual human and have faith and fear the God Almighty, a good character, health, knowledge, ability, creative, independent, and be a democracy and responsibility citizen of nation. In other words, in order to the aim education, one influence is curriculum which students have the character and knowledgeable.

The curriculum at all levels of the education system in Indonesia is the 2013 
curriculum and the policy of applying the 2013 curriculum which is the government effort to improve the education quality in Indonesia better than before, and indeed in reality that the application of the policy requires quite a long time to be achieved as expected, 2013 curriculum success, but with so many changes, renewal will achieve success. A policy or regulation is made and applied to every system of education which is very dependent on the perspective of the teacher in addressing the changes that must be applied as well as on the implementation of English in teaching and learning activities in the classroom. The perspective depends on many things such as the education background of the English teacher and the experience of the English teacher in conducting the teaching and learning process. Therefore, the implementation of the 2013 curriculum on learning English depends on the way of thinking of the English teacher, as said Lunsberg and Levin (2003), Richardson,2003; Basturkman Lowen, and Ellis, 2004, Senior 2006 in Djuwairah, A\&Mardiana (2012). Basically, every curriculum policy implementation imposed by the government is largely determined by the ability of teachers to implement it properly. The implementation is more or less influenced by the perceptions and interpretations held by the teacher. Teachers' perceptions and interpretations of the curriculum are based in the teacher's own knowledge and experience.

SMA Kartika VIII-1 Srengseng Sawah is a private school, precisely located in South Jakarta and this school has quite complete facilities, which are available in sports fields, libraries, English laboratories, the students who enter this school are students enrolled in the zoning system which has a residence not far from school.

SMA Kartika VIII-1 Srengseng Sawah Jakarta Selatan has implemented the 2013 curriculum where the curriculum used now is the 2013 revised 2018 curriculum.

Based on the observations before research that the problems of English teachers are as follows; First, based on the 2013 curriculum revised 2018 that the time for English subjects is only two hours a week, and this is not sufficient in providing English language teaching materials and English teachers are charged 24 hours and to be achieved 24 hours an English teachers must teach 24 hours performance in several classes; Second, the implementation of English learning the teachers use English in conveying material and the problem is the difficulty of students to understanding English teachers in providing English learning with use English. In addition, to the problems we describe in this study and the writers want to know the expectations of English teachers in learning English.

\section{LITERATURE REVIEW}

2.1. Curriculum 2013

According to Jusnita, N\&Ismail, N (2018) stated that curriculum 2013 is on simplification afford and thematicintegrative. 2013 curriculum was prepared to produce the ready generation in the future. Because the curriculum to anticipate the future development.

According to Kurniawan O\& Noviana, E (2017) stated Curriculum 2013 as a tool for the teachers and students to implement the learning actively. 
Based on the definition above we concluded that the 2013 curriculum as a guide to teachers for making the students become active students then found the solution about the obstacles their self, at the end of the learning making the students understand and do the innovation about something so that students found the new theory.

\subsection{English teachers}

According to Firrochiro in Maili, S (2012) states, "Teacher is one of agents determining whether the teaching will be successful or not."

According to Anggraeni, A, dkk (201) state in teacher and lecturer law stated that teacher is a professional teacher with the main task is educate, teach, guide, lead, practice, evaluate and evaluating students to the education of early childhood education program in formal education, elementary and the secondary education.

Based on the second definitions above, teacher as an educator is the important role in processing of learning at the classroom. Now, the teacher role as a facilitator that a teacher try to facilitate their self and students to use the tools in supporting the process of learning in the classroom, because teachers need it for the goal of teaching will be reached well. There are many obstacles found by the English teachers in implementing English in the classroom, and teachers' perspective is different.

According to Arifin, S ( 2011 ) states the word perspective comes from Italia "Prospettiva means" view picture". In other words, Perspective is an idea; it is obtained by the teacher to solve something through teachers' perspective.
English teachers perspective through see, evaluate different idea, for an example about the time of learning English which every teachers has a different perspective to give some an idea about the time and the English teacher perspective can be positive and negative.

\section{RESEARCH METHOD}

This research is a descriptive study with a qualitative design. According to Sukmadinata (2012) in Mastur (2017) stated that descriptive research is research that seeks to describe that exist, both phenomena that are scientific and human engineering. While qualitative is research that produces theories arising from data not hypotheses. Research in question is to collect data or information as much as possible, is descriptive, more concerned with the process than the results, limiting studies with focus, has a set of criteria to check the validity of the data, design the research is temporary and the results of the study are agreed by both parts, both by the researcher and the research subject. In this research the researcher took the data in description.

a. Research Location

This study located is SMA Katika VIII-1 Srengseng Sawah Jakarta Selatan

b. Technique of collecting the data The researcher done some steps to collect the data as follow;

1. Observation

2. Interview

\section{c. Data Analysis}

To analyze the data, the writer took the source data by observation and interview. To analyze the picture, the researcher obtained the picture when the 
English teacher taught directly. To analyze the interview the researcher analyzed the result of interview by the English teachers at class X and XI.

\section{RESULT AND DISCUSSION}

4.1. English teachers perspective about 2013 curriculum

Curriculum 2013 has been conducted simultaneously throughout Indonesia since 2018, it focused on the character education without ignoring the academic aspect. SMA Kartika VIII is a private school at South Jakarta has applied at 2013 curriculum revised 2018 plus. Based on the interview and the observation to the English teachers about their 2013 curriculum perspective which does not interfere with teaching and learning activities in the classroom where researcher conducted interviews with two English teachers by asking about the English teachers' perspective of 2013 curriculum. Two English teachers had a difference perspective about 2013 curriculum but basically both English teachers have a positive perspective about the 2013 curriculum.

Teacher A: I think that the 2013 curriculum can be positive and good, teachers can apply the 2013 curriculum is the teacher who want to innovate and be creative, each class will be a difference to convey the materials because the conditions of the students are also differ.

Teacher B: My perspective on the 2013 curriculum is very good if it was implicated only 25 students. Meanwhile, SMA Kartika VIII-1 had above 30 students in a class and it did not be optimal.
Based on the English teacher perspective above the English teachers received the 2013 curriculum positively, even though there are obstacles showing such as the large number of students so that the application of learning English is not optimal.

\subsection{English teachers perspective about the implementation of learning English \\ Learning English at Senior High} School has been implemented since old time and the English implementation in the classroom by using 2013 curriculum which is underwent the policy of change, because every change of policy is required to experience changes also in implementing the 2013 curriculum. For an examples in implementing KTSP and 2013 curriculum are difference in implementation of KTSP in English learning in the classroom which focus on competency, so now students are able to have the competence of listening, how students can hear well, so that they can understand dialogue in English; Reading, how the students can or are able to read vastly and understand wacana correctly; and able to answer question correctly; Writing, how the students are able to write by using a good grammar. But in 2013 curriculum main focus on character education where development of lesson plan must be integrated into character education. The implementation of learning English at SMA Kartika VIII-1 Srengseng Sawah Jakarta Selatan which every teacher made a different perspective but basically, the English teachers' perspective is positive. English, as stated English teachers based on the interview below: 
Teacher A: In the implementation of learning English in the classroom which the students must be able to use in written and spoken English

Based on the result of the interview above that English teacher perspective to make students able to understand the material presented and try to use it in written and spoken language, even though in its implementation there are some obstacles as answered by the English teacher below;

Teacher A: Time for the application of English two hours of study is not enough because the discourse must be understand, expressions must be memorized, writing structure must be in accordance with grammar, and dialogue must be able too.

Teacher B: In class hours are deemed in appropriate because too few hours a week are only two hours.

In the English implementation used 2013 curriculum revised 2018 which English is given two hours while the materials delivered by English teachers is so much and the skill to be transferred to students are not sufficient with the time allocated only two hours of study. Because the time given is only two hours in completing the materials provided, the implementation of five learning activities such as observe, ask, collect, and associate and communicate the result demanded by the 2013 curriculum has not been fully carried out by English teachers until SMA Kartika VIII-1 runs optimally but not. Based on the observation that the English learning implementation, such preliminary activities the English teacher has given questions to students regarding the material provided and the teachers takes students to real-life experiences, while in the five care activities there are still activities that have not been carried out by the teacher because they are constrained by the time allocated only two hours. In the core activity constraints found were English teachers used English as a tool of communication in deliver material, there are students who do not respond well, but this is a homework assignment for teacher to remain enthusiastic in delivering English material in using English. Finally, the closing activity, English teacher in accordance with the implementation of learning based on he 2013 curriculum that is, the teachers and the students do the lesson conclusions given by the English teacher.

\subsection{English teacher expectations about high school English learning}

Every teacher has an expectation of the profession he/she is occupying, so English teachers at SMA Kartika VIII-1 Srengseng Sawah Jakarta Selatan after giving the English learning and found is the obstacles to implementation the material, so English teacher has a hope in the future about the English learning high school, such as the result of interview to the English teacher below as follow;

Teacher A: English is still given at the Senior High School level as long as the time before the 2013 curriculum is revised i.e. 4 hours so that the maximum is especially helpful for the 
students who are unable to take the lessons outside of school.

Teacher B: More activities such as training workshop or learning workshops that support teachers' competence plus more source book in the library and additional hours of learning in a week

Every teacher as well as English teacher have hope in the future towards learning English, in essence the expectation of English teachers is that they ask for additional hours of English language lessons for several reasons;

1. The material presented is so extensive so it takes four hours of study

2. In implementation of English learning at SMA English teachers are required to apply the inquiry method whereas when applying this method time given to students are not be transferred the maximal the knowledge if it only two hours of the subject

3. The material is integrated on the character education when deliver English material is Lesson Plan that made of teachers must be integrated on the character education, it needs not only two hours, after done observation directly in the classroom by using video, we observed that before teachers gave the materials to students so there is character education as follow students gave greetings in English, and taking the attendant list students sits quietly material provided by English teacher. Based on the result of observation and interview to the English teachers that the main problems is the time mentioned in 2013 curriculum revised 2018 is still not sufficient to implement English learning in the classroom.

\section{CONCLUSION}

Based on the result at SMA KARTKA VIII-1 Jakarta Selatan which of the interview about English teacher perspective to 2013 curriculum very positive that the English teacher understand the concept of 2013 curriculum, but the implementation of English teachers perspective are the same about the time that the English teachers did not use of the scientific method because the time is given was not enough and the materials of the English lesson was a great. The researcher also given the solution First, the 2013 curriculum returned to the curriculum 2013 before revised which is English is given 4 hours in a week; Second, The English scientific method was used by the English teachers which it need a long time so it considered to adding the time; Third, The English teacher training at the private school need to be raised.

\section{REFERENCES}

Anggraeni, A, dkk (2019). Profesi Kependidikan. Jakarta: Unidra Press.

Djuwariah, A \& Mardiana (2014). Kurikulum 2013 Dalam Persepsi Dan Interpretasi Guru-Guru Bahasa Inggris SMA Kota Makassar. BAHTERA: Jurnal Pendidikan Bahasa dan Sastra. 13(1), 72-80. 
https://doi.org/10.21009/BAHTE

RA.131.07

Egar, N, Musarokah, S, dan Yulianti, F. (2014) Implementasi Kurikulum 2013 Oleh Guru Bahasa Inggris Di SMA Neeri Pilot Project Pelaksanaan Kurikulum 2013 Kota Semarang. Seminar Nasional Hasil Penelitian (SNHP-IV) Lembaga Penelitian Dan Pengabdian Kepada Masyarakat Universitas PGRI Semarang.

Firocchiro dalam Maili, S (2012). The Suitability of The English Textbook used AT SD Al-Azhar 20 Cibubur Based on KTSP. Thesis Universitas Muhammadiyah Prof.Dr. Hamka. Jakarta.

Jusnita, N \&Ismail, A (2018). Implementasi Kurikulum 2013 Dalam Pembelajaran Bahasa Inggris Di SMP Kota Ternate. EDUKASI Jurnal Pendidikan. 2(2), 269-283. https://ejournal.staimadiun.ac.id/i ndex.php/annuha/article/view/49

Kurniaman. O \& Noviana, E (2017). Penerapan Kurikulum 2013 dalam Meningkatkan Keterampilan, Sikap, dan Pengetahuan. Primary: Jurnal Pendidikan Guru Sekolah Dasar. 6(2), 389-396.

https://www.ejournal.unri.ac.id/i ndex.php/JPFKIP/article/downlo $\mathrm{ad} / 4520 / 4314$
Hasbullah, M, H (2015). Kebijakan Pendidikan. PT Raja Grafindo Persada. Jakarta

Mastur. (2017). Implementasi Kurikulum 2013 Dalam Pelaksanaan Pembelajaran Di SMP. Jurnal Inovasi Teknologi Pendidikan. 4(1), 50-64. https://doi.org/10.21831/jitp.v4i1 .10131 . 
Vol. 7 No.l April 2020

e-ISSN : 2406 - 9809 p-ISSN : $2527-8835$

http://ejournal.upbatam.ac.id/index.php/basis

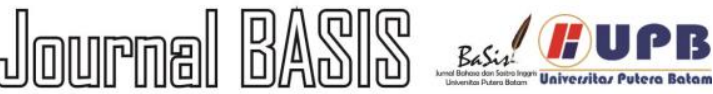

